\title{
Determination and ranking of target areas in catchments for the implementation of nitrogen reduction measures
}

\author{
B. Tetzlaff ${ }^{1}$, R. Kunkel ${ }^{2}$, W. Schäfer ${ }^{2}$, and F. Wendland ${ }^{1}$ \\ ${ }^{1}$ Research Centre Jülich, Institute of Chemistry and Dynamics of the Geosphere (ICG), Institute IV: Agrosphere, \\ 52425 Jülich, Germany \\ ${ }^{2}$ State Authority for Mining, Energy and Geology, Lower Saxony, 30655 Hannover, Germany
}

Received: 11 January 2007 - Revised: 5 April 2007 - Accepted: 22 May 2007 - Published: 13 June 2007

\begin{abstract}
The implementation of the EU Water Framework Directive (EU-WFD) forms the background of the WAgriCoproject (Water Resources Management in Cooperation with Agriculture). WagriCo concentrates on the development of nitrogen management options adapted to hydrological and agro-economic site conditions and at demonstrating new participation approaches and technologies suitable for settingup programmes of measures. The article outlines the conceptual model approach and its application in the pilot region "Große Aue" (Northern Germany). Furthermore the process of delineating priority areas is described, which act as spatial targets for the adaptation of regionally differentiated nutrient reduction measures.
\end{abstract}

\section{Introduction}

The implementation of the the EU Water Framework Directive (EU-WFD) forms the background of the WAgriCoproject (Water Resources Management in Cooperation with Agriculture). The implementation schedule for the EU water framework directive requires the creation of monitoring programmes for water bodies according to the intensity of the pollution risk by the end of 2006. Until 2009 river basin district management programmes have to be established followed by the implementation of measures from the management plans (until 2012). WagriCo is a collaborative project funded by the European Commission Life Fund 2005-2008, involving six British and four German institutions. The project aims are to aid the implementation of the Water Framework Directive, to develop nitrogen management options adapted to hydrological and agro-economic site properties and to demonstrate the use of new participation approaches and technologies suitable for programmes of

Correspondence to: $\mathrm{B}$. Tetzlaff

(b.tetzlaff@fz-juelich.de) measures to reduce diffuse pollution from agriculture and to promote sustainable water resources management. On the basis of a pollution risk assessment, the environmental objectives will be specified and measures for endangered water bodies will be specified, discussed with the local stakeholders and implemented at farm level. The results achieved in the pilot areas and the socio-political, financial, geographical and hydrological factors influencing the impact of the measures are evaluated. On the basis of an extrapolation to Federal State level, the administrative requirements for statewide implementation are specified and evaluated. In this paper we will focus on the assessment of the pollution risk and the geographical prioritization for measures in catchment areas.

\section{Investigated area}

Within the WAgriCo project, six pilot study areas have been selected in the UK and in Germany. One of the selected case study areas is located in the river basin Große Aue, a tributary to the river Weser basin and geographically situated in the Federal State of Lower Saxony, Germany (see Fig. 1). The Große Aue pilot area is a groundwater body with a size of about $1000 \mathrm{~km}^{2}$. About $55 \%$ of the lands surface of this groundwater body is used agriculturally, in about $20 \%$ of the area peaty soils under peat cutting can be found. Therefore, the natural conditions in groundwater and surface waters are expected to be significantly influenced by anthropogenic interferences into $\mathrm{N}$ - and water balance and runoff regimes.

\section{Conceptual model}

The WAgriCo project is based around the catchment management process. For basic understanding of interactions between the issues mentioned in chapter 1 a conceptual integrated hydrological/hydrogeological model (see Fig. 2) has

Published by Copernicus Publications on behalf of the European Geosciences Union. 


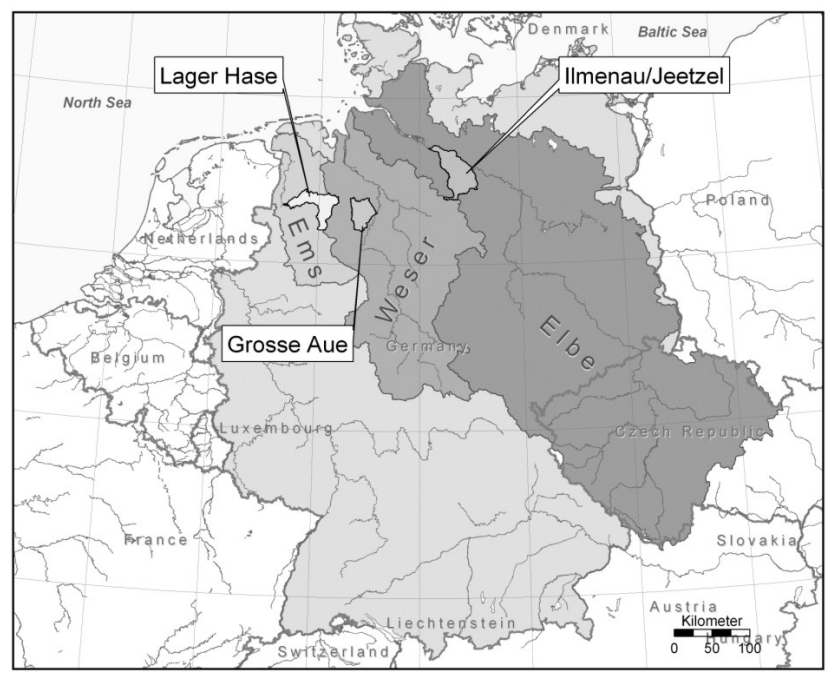

Fig. 1. German pilot study areas in the WAgriCo project.

been set up. The model consists of three main features: natural characteristic assessment, anthropogenic impact assessment using monitoring data and model tools providing a linkage between the first two parts.

Based on the conceptual model the interactions between agricultural practice, nitrogen surpluses, nitrogen concentration in both leachate and groundwater are analyzed. In the same way modelling nitrogen inputs into surface waters and, finally, the characterization of the groundwater status are carried out. In the following sections selected natural characteristics, monitoring data and model tool application results are presented for the Große Aue case study area. As all of the applied model tools have been already described in detail in the literature (e.g. Kunkel and Wendland, 1997, 2002, 2006) this paper will concentrate on a brief description.

\subsection{Natural characteristics}

The natural site conditions represent an important basis for the understanding of groundwater status. In a first step, a hydrogeological characterization has been done using a number of different data sets available on a Federal State level, e.g. from geological maps, geological/hydrogeological profiles and the distribution of clay covers above the aquifers. A hydrochemical/hydrodynamic characterization of groundwater has been performed using data on the hydraulic conductivities and the groundwater pressure heads of the upper aquifers, as well as groundwater quality data related to the redox and salinization state of the aquifers. From all data available for the Federal State of Lower Saxony a number of data sets have been selected, which are of particular importance for the assessment of natural characteristics. These data, listed in Table 1, are often not only used for natural characteristics assessment but also input parameters for model tools, e.g. for water balance or reactive subsurface nutrient transport modelling.

As an example for the assessment of natural characteristics, Fig. 3 shows the denitrification conditions in the soils for the Große Aue pilot area. This parameter has been derived from the soil map 1:50 000 of Lower Saxony on the basis of soil type and groundwater influence information. Apparently, the denitrification conditions vary from very bad to very good within the pilot area. Good to very good denitrification conditions occur in peatlands of the central part and in groundwater influenced floodplains. In contrast, the northern Geest part of the pilot area, dominated by sandy soils, bad to very bad denitrification conditions are to be found. In those regions, nitrate inputs may reach the groundwater after a relative short period of time without any significant denitrification.

\subsection{Monitoring data}

Because of anthropogenic influences the status of groundwater and surface waters is different compared to the natural characteristics. In particular, in the status review of German's groundwater bodies according to the EU-WFD the Große Aue groundwater body has been classified as at risk because of a potential failure of good status, primarily due to high nitrate concentrations. Monitoring programs have been initiated to quantify the amount of anthropogenic intakes e.g. of nutrients into the soil, groundwater and surface waters. Data from different monitoring programs are available, indicating the concentrations of various substances (e.g. nutrients) in groundwater and surface waters.

Figure 4 shows measured nitrate concentrations in the groundwater using data from monitoring wells. It can be seen clearly that the nitrate concentrations are typically very low. In areas covered by clay layers, concentrations are less than $2 \mathrm{mg} \mathrm{NO} 3 / \mathrm{l}$ in most cases, indicating a possible denitrification due to reduced aquifer conditions. This is confirmed by an analysis of the $\mathrm{Fe}^{2+}$ and $\mathrm{O}_{2}$-concentrations in those areas (Kunkel et al., 2004). In contrast uncovered surface-near stations and, in particular, withdrawal wells from water suppliers show much higher nitrate concentrations in groundwater because of either oxidized conditions near groundwater surface or the modified flow regime due to groundwater abstraction.

The monitoring in the case study area Große Aue also comprises the intakes of nutrients into the soil, biannual measurements of the Nmin-contents in the soil as well as measurements of the nitrate concentration in the leachate. Although these kinds of data are available only for selected sites, they allow the assessment of impacts from anthropogenic inputs originating from diffuse or point sources. 


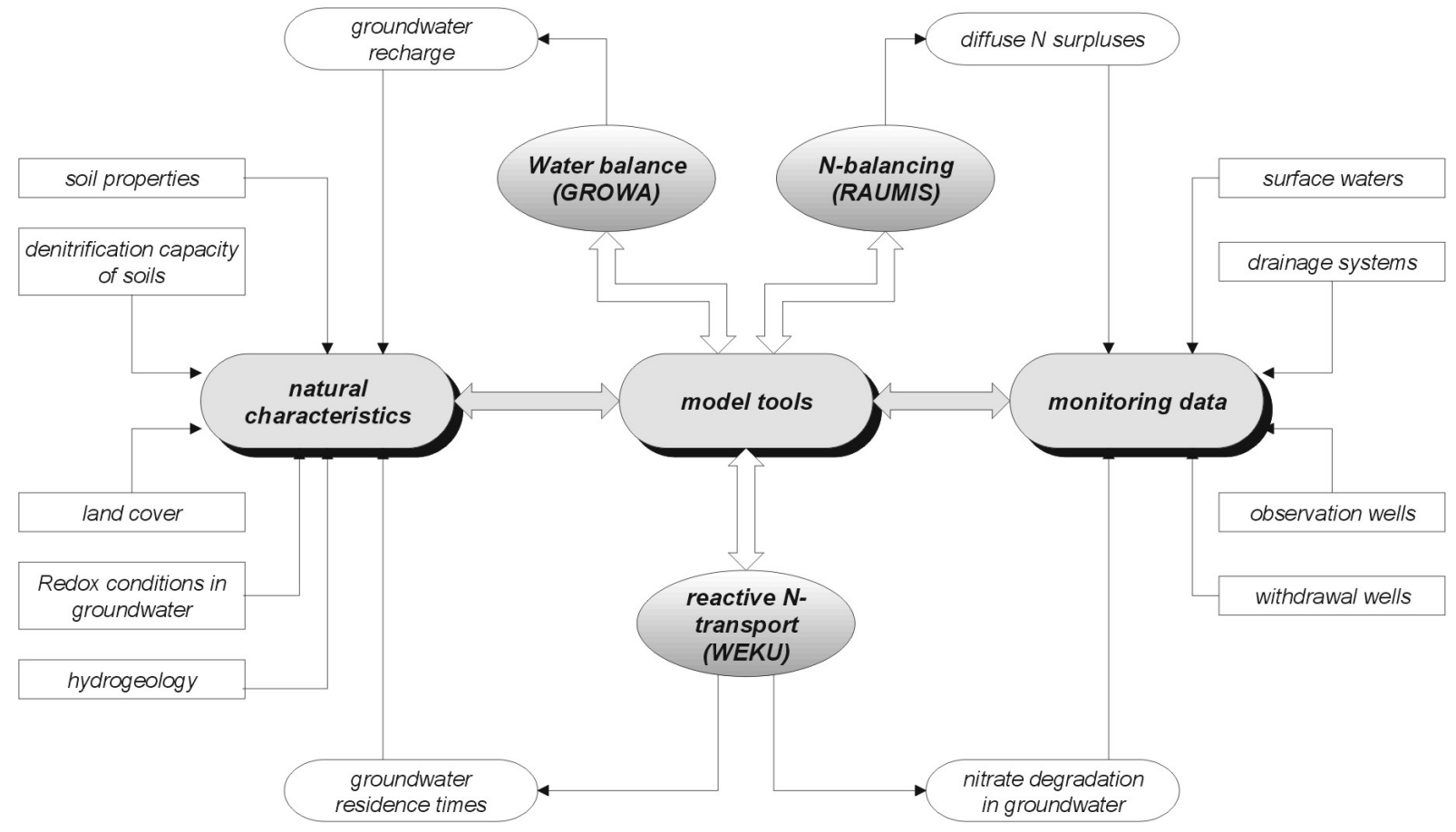

Fig. 2. The hydrological-hydrogeological conceptual model.

Table 1. Used data sets for target area assessment.

\begin{tabular}{|c|c|c|}
\hline & Data set & Scale \\
\hline Land cover & Landcover categories & $1: 25000$ \\
\hline Agricultural production & $\begin{array}{l}\text { Animals } \\
\text { Cultivation } \\
\text { Harvest } \\
\text { Mineral fertilizer }\end{array}$ & Agrarian statistical data \\
\hline Climate & $\begin{array}{l}\text { Summer precipitation levels } \\
\text { Winter precipitation levels } \\
\text { Potential Evaporation }\end{array}$ & Interpolated point data \\
\hline Topography & $\begin{array}{l}\text { Slope } \\
\text { Exposition }\end{array}$ & $50 \times 50 \mathrm{~m}^{2}$ raster \\
\hline Soil parameters & $\begin{array}{l}\text { Plant-available water } \\
\text { Denitrification capacity of soils } \\
\text { Groundwater influence }\end{array}$ & $1: 50000$ \\
\hline Hydrogeology & $\begin{array}{l}\text { Hydrogeological units } \\
\text { Geological profiles } \\
\text { Hydraulic conductivity }\end{array}$ & $1: 200000$ \\
\hline Hydrodynamics & $\begin{array}{l}\text { Depth to groundwater } \\
\text { Runoff in rivers } \\
\text { River network, drainage systems }\end{array}$ & 1:200 000 or point data \\
\hline Hydrochemistry & Groundwater monitoring data & Point data \\
\hline
\end{tabular}




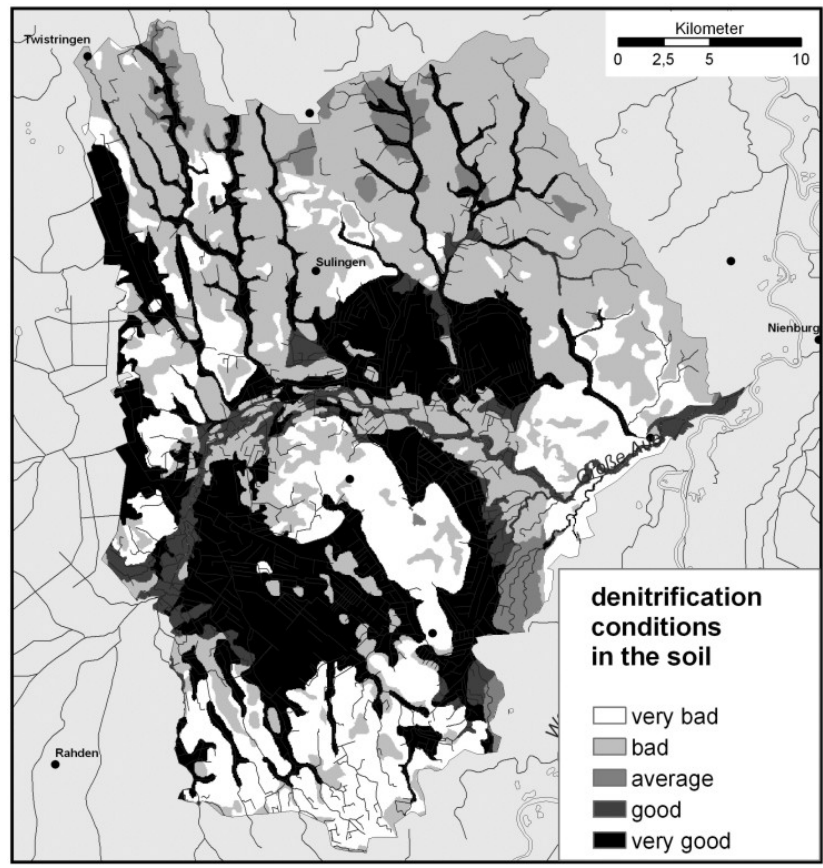

Fig. 3. Denitrification conditions in the soil.

\subsection{Model tools}

Within the conceptual model the linkage between natural characteristics, land use and status of groundwater and surface waters is provided by model tools. At present, three different tools are included in the model, considering $\mathrm{N}$ balancing, water balance and reactive $\mathrm{N}$-transport through the soil and groundwater into the surface waters (Fig. 2).

Coupling between agricultural practice and $\mathrm{N}$-surpluses in the soil is done by the agricultural sector model RAUMIS (Henrichsmeyer, 1996). Agricultural statistics, e.g. on crop yields, livestock farming and land use were taken to balance the nitrogen supplies and extractions for the agricultural area. The long-term nitrogen balance averaged over several vegetation periods is calculated considering the organic nitrogen fertilization, the mineral nitrogen fertilization, the symbiotic $\mathrm{N}$-fixation, the atmospheric $\mathrm{N}$-inputs and the $\mathrm{N}$-extractions with the crop substance. As a rule, the difference between nitrogen supplies, primarily by mineral fertilizers and farm manure, and nitrogen extractions, primarily by field crops, leads to a positive N-balance (Gömann et al., 2004).

The displacement of $\mathrm{N}$-surpluses from soil to groundwater and surface waters is coupled to runoff components. Against the background of a long-term treatment, runoff was distinguished into the relevant runoff components for nitrate emissions to surface runoff: surface runoff, direct runoff, drainage runoff and groundwater runoff. Whereas direct and drainage runoff reaches the surface waters within short time periods (within about a week), groundwater run-off needs much more time (years) to percolate into surface waters. The runoff com-

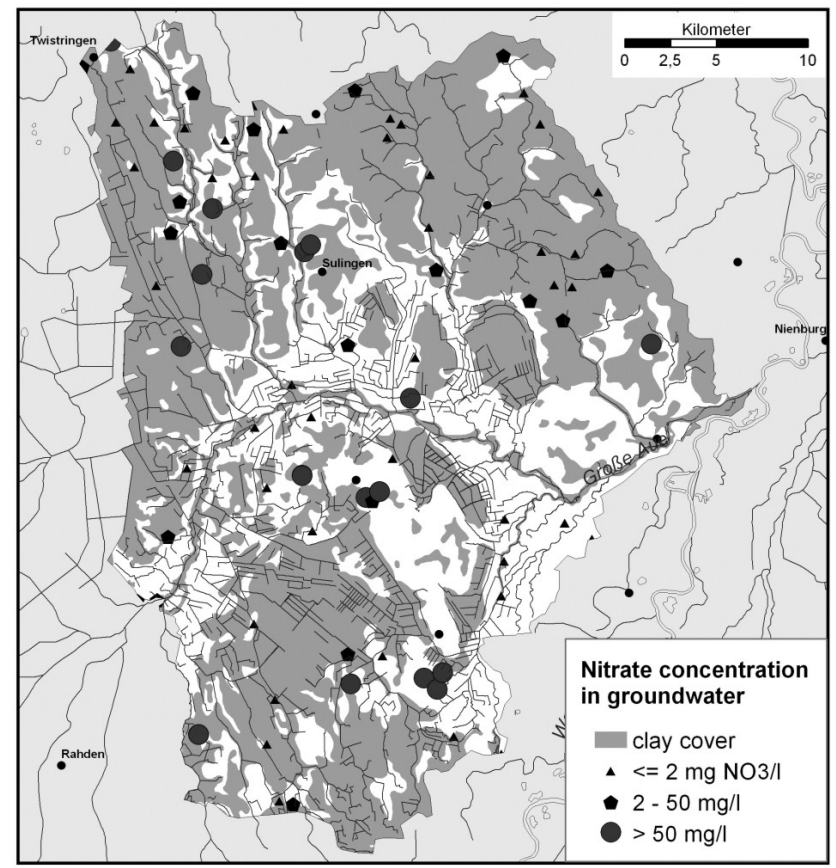

Fig. 4. Measured nitrate concentration in the groundwater.

ponents were quantified area-differentiated considering climate, soil, geology, topography and land use conditions using the GROWA model (Kunkel and Wendland, 2002). The groundwater recharge level is an important model based parameter for the assessment of natural characteristics. Additionally, the ratio between groundwater recharge and total runoff levels was taken as a measure for the extent diffuse nitrogen surpluses, which are displaced from soil to groundwater (Kunkel et al., 2004; Wendland et al., 2002). For the northern and the southern parts of the pilot area, the groundwater recharge amounts to $80 \%$ or more of total runoff. In those areas, the nitrate leached out of the soil will reach the groundwater area almost complete. In the floodplains along the rivers and in the central part of the pilot area, the groundwater recharge is reduced to the advantage of direct runoff due to groundwater influence of the soils and the existence of artificial drainage systems. A significant part of the nitrate washed out of the soils will reach the surface waters via direct or drainage runoff without leaching into groundwater.

During transport through soil and groundwater nitrogen surpluses may be denitrified to molecular nitrogen. Denitrification losses in the soil occur mainly in the root zone in case of low oxygen and high water contents as well as high contents of organic substances. In a Michaelis-Menten kinetics approach these denitrification conditions were combined with the calculated nitrogen surpluses and the residence times of the percolation water in the root zone calculated as a function of average field capacity and the percolation runoff level (Kunkel and Wendland, 1997). 


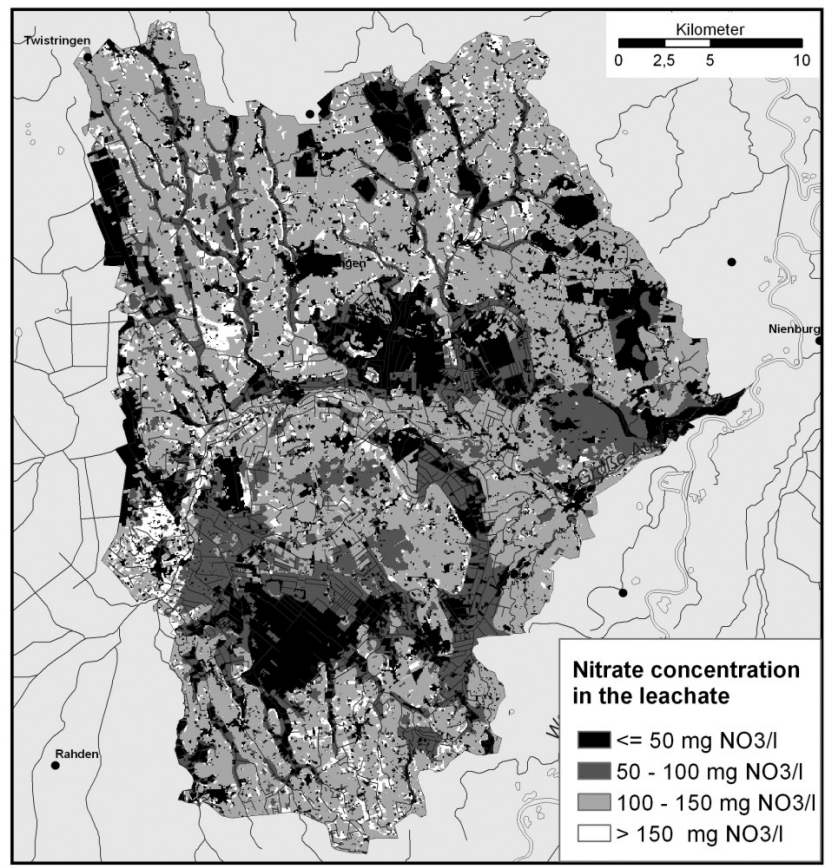

Fig. 5. Calculated nitrate concentration in the leachate.

The potential nitrate concentration in recharged groundwater is a modelled parameter, which combines Nitrogen surpluses from agriculture, water balance and denitrification in the soil. It is calculated using the GROWA-WEKURAUMIS model tools and displayed area-differentiated in Fig. 5. As to be seen from the map, nitrate concentrations above $100 \mathrm{mg} \mathrm{NO}_{3} / 1$ are calculated for the major part of the pilot area. Only for the peaty areas and the floodplains with high denitrification potentials in the soil lower nitrate concentrations have been calculated. This is in line with the observed situation in the upper part of the aquifers.

A comparison between Figs. 4 and 5 shows, that the observed nitrate concentration in groundwater is much smaller than nitrate concentration in the leachate. This is due to denitrification processes in the aquifer, which are well known for larger parts of the North-German Lowlands where the Große Aue is located (Böttcher et al. (1989) and Walter et al. (2004)). However, although denitrification in groundwater is relative effective - extensive field studies indicate a halving of nitrate load in groundwater after a residence time between 1.2 and 4 years - the process irreversibly consumes pyrite and/or organic carbon reservoirs in the aquifer. In contrast to nitrate degradation in the soil denitrification in groundwater cannot be regarded as being inexhaustible.

Reactive nitrate transport in groundwater was modelled using the stochastical WEKU model (Kunkel and Wendland, 1997) on the basis of a first order reaction depending on the nitrogen inputs into the aquifer, denitrification conditions in groundwater and groundwater residence times. These parameters allow an assessment of the time-lags between the

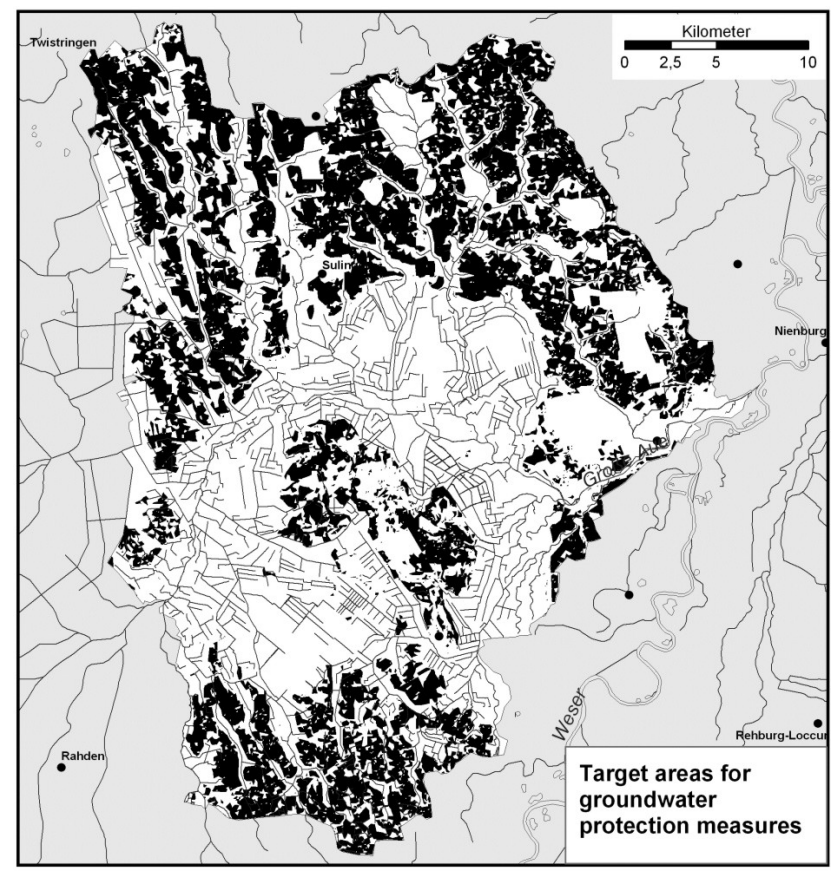

Fig. 6. Delineated target areas for groundwater protection measures.

implementation of certain mitigation measures and its effect on the groundwater or surface water quality.

\section{Delineation of target areas}

For the delineation of environmental target areas for nitrogen reduction measures it has to be distinguished whether the main focus should be on groundwater protection or surface water protection. Only under consideration of the receptors of the nitrate inputs, target areas can be defined. In the following sections the consequences of this are demonstrated for both, surface waters and groundwater as receptor.

\subsection{Target areas for surface water protection}

In the case of surface water protection nitrate inputs from all runoff components - direct runoff, drainage runoff and groundwater runoff - need to be considered. Hence, target areas should be delineated from those areas, which contribute most to nitrate intakes into the river systems. Due to denitrification processes in the aquifers of the Große Aue, groundwater-borne nitrate intakes into the surface waters play a minor role compared to intakes from direct runoff, mainly by artificial drainage systems. Thus, possible mitigation measures for surface water protection imply either $\mathrm{N}$ surplus reduction or blocking of artificial drainage systems. 


\subsection{Delineation of target areas for groundwater protection}

In contrast possible mitigation measures to reduce nitrate concentrations in groundwater imply only the reduction of $\mathrm{N}$ inputs to groundwater. Target areas for groundwater protection are delineated from those areas, which contribute most to nitrate intakes into groundwater. Therefore, agricultural areas on soils with bad or very bad denitrification capacity and high portion of groundwater recharge are considered as target areas. The delineated target areas for the Große Aue pilot area are shown in Fig. 6. A large part of the arable land in the groundwater recharge areas north and south of the floodplains are selected as target areas for groundwater protection. In all of these target areas, the calculated nitrate concentration in the leachate is above $100 \mathrm{mg} \mathrm{NO}_{3} / \mathrm{l}$.

Groundwater protection is an important part of surface water protection but, furthermore, focuses directly on issues concerning public water supply. It is an ongoing discussion between the EU-member states, whether the groundwater "as itself" needs to be protected or if the "usability" of groundwater for human demand is the main focus. This has direct implications on the environmental targets, which have to be defined prior to the delineation of target areas or the evaluation of protection measures. If, for example, the "usability" of groundwater is protected, the drinking water limit of $50 \mathrm{mg} \mathrm{NO}_{3} / 1$ in groundwater needs to be ensured at least for drinking water extraction areas.

Because of possible nitrate degradation in the aquifers of the Große Aue, $50 \mathrm{mg} \mathrm{NO}_{3} / \mathrm{l}$ can be reached in most parts of the aquifer even in case of much larger nitrate concentrations in the leachate. Only in the vicinity of withdrawal wells, higher nitrate concentrations are observed because of the modified flow regime. Hence, reduction measures to reach the environmental target of $50 \mathrm{mg} / \mathrm{l}$ would only have to be implemented in areas used for groundwater extraction.

Another aspect has to be taken into account when environmental targets for groundwater protection are defined. Denitrification in groundwater is associated with the irreversible consumption of substances in the groundwater, such as pyrite and organic carbon. Once these substances are exhausted nitrate can not be denitrified in groundwater any more. As a consequence, nitrate concentrations would start to rise, like it has been described for many sites already. Consequently, the denitrification buffer of groundwater systems has to be prevented from damage, which implies a reduction of $\mathrm{N}$-intakes into groundwater. A capable environmental target may be the nitrate concentration in the leachate. A limit of $50 \mathrm{mg} \mathrm{NO}_{3} / \mathrm{l}$ would ensure a "good groundwater quality status" with respect to general quality standards even in the case of missing or exhausted nitrate degradation capacities in the aquifer.

Scenario analyses were conducted in order to derive the amount of $\mathrm{N}$-surpluses, which has to be reduced, when a concentration of $50 \mathrm{mg} \mathrm{NO}_{3} / \mathrm{l}$ in the leachate should be achieved for all individual sites. For most regions, especially in the northern part of the pilot area, a N-surplus reduction of more than $25 \mathrm{~kg} \mathrm{~N} /($ ha a) is necessary. Compared to the actual $\mathrm{N}$ surpluses the required reduction would be larger than $40 \%$ in most areas. It becomes evident that this reduction could only be achieved by massive changes in agricultural production, which would lead to significant consequences for the affected farmers.

\section{Conclusions and outlook}

The previous sections have shown, that for the delineation of environmental target areas for nitrogen reduction measures it has to be distinguished whether groundwater protection or surface water protection is the main focus. Only under consideration of the receptors of the nitrate inputs targets areas can be defined. Therefore, the next steps in the WAgriCo project are straightforward. First, it is necessary to achieve an agreement on the environmental targets in the participation process between the stakeholders. Measures, which are effective for surface and/or groundwater with respect to cost and impact need to be selected and implemented in the pilot areas. The consequences for the farmers concerning land management and income losses need to be evaluated and programmes for an effective distribution of available funding of measurements at farm level need to be compiled and implemented.

Edited by: K.-E. Lindenschmidt

Reviewed by: H. Nacken and G. Petersen

\section{References}

Böttcher, J., Strebel, O., and Duynisveld, W. H. M.: Kinetik und Modellierung gekoppelter Stoffumsetzungen im Grundwasser eines Lockergesteinsaquifers, Geologisches Jahrbuch C, 51, 3 40, 1989.

Gömann, H., Kreins, P., Kunkel, R., and Wendland, F.: Model based impact analysis of policy options aiming at reducing diffuse pollution by agriculture: a case study for the river Ems and a subcatchment of the Rhine, Environ. Modell. Softw., 20(2), 261271, 2004.

Henrichsmeyer, W., Cypris, Ch., Löhe, W., Meudt, M., Sander, R., and v. Sothen, F.: Entwicklung eines gesamtdeutschen Agrarsektormodells RAUMIS 96, Endbericht zum Kooperationsprojekt, Institut für Agrarpolitik, Marktforschung und Wirtschaftssoziologie der Universität Bonn, Institute für Betriebswirtschaft, Strukturforschung und Landwirtschaftliche Marktforschung der Bundesforschungseinrichtung für Landwirtschaft (FAL), Bonn, Braunschweig, Germany, 1996.

Kunkel, R. and Wendland, F.: WEKU; a GIS-supported stochastic model of groundwater residence times in upper aquifers for the supraregional groundwater management, Environ. Geol., 30(12), 1-9, 1997.

Kunkel, R. and Wendland, F.: The GROWA98 model for water balance analysis in large river basins; the River Elbe case study, J. Hydrol., 259(1-4), 152-162, 2002. 
Kunkel, R., Bach, M., Behrendt, H., and Wendland, F.: Groundwater-borne nitrate intakes into surface waters in Germany, Water Sci. Technol., 49(3), 11-19, 2004.

Kunkel, R. and Wendland, F.: Diffuse Nitrateinträge in die Grundund Oberflächengewässer von Rhein und Ems, Schriften des Forschungszentrums Jülich, Reihe Umwelt/Environment, Band 62, Forschungszentrum Jülich GmbH, Jülich, Germany, 2006.

Walther, W., Reinstorf, F., Pätsch, F., and Weller, D.: Management tools to minimize nitrogen emissions into groundwater in agricultural used catchment areas, northern low plain of Germany, Proceedings of "XXX IAHR Congress: Water engineering and research in a learning society", 24-29 August 2003, Thessaloniki, Greece, Vol. B, 747-754, 2003.
Wendland, F., Bach, M., Behrendt, H., and Kunkel R.: Integrated modelling of groundwater-borne nitrate intakes into the river Elbe basin (German part), Proceedings of the 9th International Specialized Conference on River Basin Management, Edinburgh, Scotland, 2002. 